\title{
Sampling design for efficient detection of pine wood nematode, Bursaphelenchus xylophilus, in diseased trees using a DNA detection kit: variation across branch, trunk and tree
}

\author{
Yuuki NAKABAYAshi ${ }^{1}$, Takuya AiKawA ${ }^{2}$, Michinari Matsushita ${ }^{3}$ and Kazuhiko HoshizAKi ${ }^{1, *}$ \\ ${ }^{1}$ Department of Biological Environment, Akita Prefectural University, Akita 010-0195, Japan \\ ${ }^{2}$ Tohoku Research Center, Forestry and Forest Products Research Institute, Morioka 020-0123, Japan \\ ${ }^{3}$ Forest Tree Breeding Center, Forestry and Forest Products Research Institute, Ibaraki 319-1301, Japan
}

Received: 6 December 2017; revised: 14 February 2018

Accepted for publication: 15 February 2018; available online: 20 March 2018

\begin{abstract}
Summary - Detection of pine wood nematode, Bursaphelenchus xylophilus, is fundamental for effective control of pine wilt disease. Recent molecular techniques, such as DNA detection, have enhanced detectability of the nematodes whereas appropriate field sampling has received less attention. In order to elucidate a sampling design that most efficiently detects B. xylophilus using a commerciallydistributed DNA detection kit, we compared detection levels of B. xylophilus using wood chips taken from various positions on dead trees. Results showed that the DNA kit had a higher detection level than the conventional method, and that trunk samples had higher levels than branch samples. Statistical model revealed that among-tree variation influenced the detectability more strongly than withintree variation. Our results suggest that, in practice, with limited resources for control, it is more efficient to take samples from many trees with a minimum number from each tree, rather than taking many samples from a small number of trees.
\end{abstract}

Keywords - foliage colour, nematode control, pine wilt disease, sampling efficiency.

Pine wilt disease is an epidemic disease of pine trees caused by the pine wood nematode, Bursaphelenchus $x y$ lophilus (Steiner \& Buhrer, 1934) Nickle, 1970 (Kiyohara \& Tokushige, 1971), and vectored mainly by the insect Monochamus alternatus (Mamiya \& Enda, 1972; Morimoto \& Iwasaki, 1972). This disease has caused severe damage to pine forests in eastern Asia, including Japan, Korea and China, and recently has invaded Portugal and Spain (Kishi, 1995; Mota et al., 1999; Abelleira et al., 2011; Robertson et al., 2011). The degradation of pine stands caused by heavy damage from this forest pest has led to a variety of concerns ranging from domestic forestry productivity through wood quality and the timber trade to cascading effects on species interactions and ecosystems (Mota \& Vieira, 2008; Rodrigues et al., 2010; Fukasawa, 2016).

In controlling the disease, detection of the infection source is fundamental for adopting various control methods. Classically, the detection of B. xylophilus has been based on the Baermann funnel technique (Southey, 1986), which extracts nematodes in water using wood chips taken from the trunks of dead trees. However, this conventional method has some difficulties. First, when the nematode density is quite low nematode extraction is likely to be unsuccessful (Mamiya, 1975; Zhao et al., 2009), leading to a 'false negative' result. Second, in dead pine trees a number of nematode species co-occur (Kiyohara, 1989), and species identification is thus necessary for any extracted nematodes. For the precise identification of species microscopic observations are required, which is only feasible using trained personnel.

Recently, several molecular-based detection methods for B. xylophilus have been developed (Matsunaga \& Togashi, 2004; Takeuchi et al., 2005; Leal et al., 2007; Kikuchi et al., 2009). These new methods can detect $B$. xylophilus faster and with a greater sensitivity than the Baermann funnel method and thus provide opportunities to mitigate the false negative results. Among those, the Bursaphelenchus xylophilus Detection Kit (Nippon Gene Co. Ltd, Tokyo, Japan), based on loop-mediated isothermal amplification (LAMP; Notomi et al., 2000), amplifies only B. xylophilus DNA (Kikuchi et al., 2009),

* Corresponding author, e-mail: khoshiz@akita-pu.ac.jp 
and provides users with an easy and powerful tool for inspecting for B. xylophilus (Aikawa et al., 2010). This DNA kit does not require particular training in molecular techniques, such as PCR, or species identification of nematodes, and is advantageous for users in terms of cost and necessary equipment compared with other molecularbased detection methods that require costly equipment (e.g., real-time PCR).

However, in terms of practice, less attention has been paid to appropriate field sampling efforts for inspection via molecular diagnosis methods, in contrast to the Baermann funnel technique for which useful recommendations have been provided (Schröder et al., 2009). In the case of the Bursaphelenchus xylophilus Detection Kit, several authors have found substantial horizontal (i.e., among-tree) variation (Kanetani et al., 2011; Hoshizaki et al., 2016). It remains to be determined if inspection along a vertical direction helps to reduce false negatives. In addition, diagnosis via the DNA detection kit is based on only a few wood chips. The developers of the kit recommend testing each sample repeatedly (Aikawa et al., 2010), but repetitions should preferably be minimised for practical reasons (i.e., the detection kit is costly). Examination could thus be significantly improved by using an efficient sampling method that minimises the cost but provides a robust diagnosis.

In the present study, we first checked if the DNA detection kit really showed a higher diagnosis performance, i.e., better nematode detection, than the conventional Baermann funnel method. Then we compared the detectability of B. xylophilus via the DNA detection kit, based on samples taken from various positions on diseased trees. Specifically, we performed the following comparisons: i) branch $v s$ trunk; ii) green foliage $v s$ brown foliage on branches; and iii) lower vs middle vs higher position of the trunk. Based on these, we evaluated what is the most efficient sampling design for users to detect pine wood nematodes using the DNA kit, thereby minimising false negatives.

\section{Materials and methods}

\section{TEST TREES}

The present study was undertaken in a coastal pine forest in Akita, northern Honshu, Japan $\left(39^{\circ} 48^{\prime} \mathrm{N}, 140^{\circ} 02^{\prime} \mathrm{E}\right.$; 15-25 m a.s.1.; Hoshizaki et al., 2005, 2016). The annual mean temperature in Akita City is $11.8^{\circ} \mathrm{C}$, with a maximum of $25.0^{\circ} \mathrm{C}$ in August. Precipitation is $1708 \mathrm{~mm}$ year $^{-1}$ and falls as snow during December-March. Dam- age in this forest has remained mild. We have continued to monitor tree damage in the study area on a monthly basis and the annual incidence of damaged trees has ranged from 0.1 to $2.4 \%$ (Ohta et al., 2012). The flight season of the nematode vector M. alternatus is from late June to late September (infection period of the disease; Hoshizaki et al., 2005). In this region, pine wilt disease invaded at least 20 years ago (Ohta et al., 2012), and in recent years we have no record of $B$. mucronatus, which does not cause pine wilt.

In August 2012 we identified three test trees (Trees 1-3) and added an additional test tree (Tree 4) in September 2012. At the selection of the test trees, all were showing symptoms of the early stages of disease development; branches with green foliage and those with brown foliage were mixed within the tree crown, and oleoresin exudation was lost. We recorded the position of branches with green and brown foliage within the crown for each tree. The foliage colour in three out of the four test trees turned brown before all the test trees were felled in November (Table 1).

\section{SAMPLING OF WOOD CHIPS}

Within 2 weeks after the selection of each test tree, wood chip samples were taken from the trunk and branches (Fig. 1). For trunks, the wood chips were collected at $1.3,4.0$ and $7.0 \mathrm{~m}$ high by drilling into the trunk (i.e., cardinal directions) from the surface (four samples per height per tree; i.e., $\mathrm{n}=48$ for trunk samples). Each wood chip sample was sealed in a plastic bag. In this procedure, we rinsed the drill bit in $99 \%$ ethanol before each sample was collected to avoid cross-contamination of samples (Aikawa et al., 2010). For branches, we cut off four primary branches $(30 \mathrm{~mm}$ diam. at the base, two with green foliage and two with brown foliage) from each test tree, and cut off two twigs from each of the branches (eight twigs from each tree; in total, $\mathrm{n}=80$ samples). Cross-contamination of samples was avoided as described. The collected trunk and twig samples were incubated at $25^{\circ} \mathrm{C}$ for 4 weeks to facilitate nematode propagation. After incubation, each twig was sliced and sealed in a plastic bag (hereafter, 'branch sample').

For the tree that showed a low detection level (Tree 2, see Results section), the twigs and trunk were resampled 3 months after the first sampling to test if the first inspection suffered from a false negative result. In this second sampling, branch and trunk samples were collected in the same way as above $(n=20)$. The samples were incubated for nematode propagation in the same manner. 
Table 1. Basic description of the four test trees (Pinus spp.) and the progress of pine wilt disease.

\begin{tabular}{|c|c|c|c|c|}
\hline $\begin{array}{l}\text { Observation parameter: } \\
\text { Species: }\end{array}$ & $\begin{array}{c}\text { Tree } 1 \\
\text { P. densiflora }\end{array}$ & $\begin{array}{c}\text { Tree } 2 \\
\text { P. thunbergii }\end{array}$ & $\begin{array}{c}\text { Tree } 3 \\
\text { P. thunbergii }\end{array}$ & $\begin{array}{c}\text { Tree } 4 \\
\text { P. thunbergii }\end{array}$ \\
\hline Tree height (m) & 12.5 & 18.4 & 16.7 & 20.1 \\
\hline Tree diam. $(\mathrm{cm})$ & 23.6 & 23.2 & 30.9 & 33.4 \\
\hline \multicolumn{5}{|l|}{ August 25} \\
\hline Foliage colour ${ }^{1}$ & $\mathrm{~B}, \mathrm{G}$ & $\mathrm{B}, \mathrm{Y}, \mathrm{G}$ & $\mathrm{B}, \mathrm{G}$ & Not detected ${ }^{3}$ \\
\hline$\%$ brown foliage ${ }^{2}$ & 50 & 50 & 60 & - \\
\hline \multicolumn{5}{|l|}{ September 25} \\
\hline Foliage colour & B & $\mathrm{B}, \mathrm{Y}$ & $\mathrm{B}, \mathrm{G}$ & $\mathrm{B}, \mathrm{G}$ \\
\hline$\%$ brown foliage & 100 & 90 & 60 & 60 \\
\hline \multicolumn{5}{|l|}{ October 29} \\
\hline Foliage colour & $\mathrm{B}$ & B & $\mathrm{B}, \mathrm{G}$ & B \\
\hline$\%$ brown foliage & 100 & 100 & 80 & 100 \\
\hline \multicolumn{5}{|l|}{ November 21} \\
\hline Foliage colour & $\mathrm{B}$ & $\mathrm{B}$ & $\mathrm{B}, \mathrm{G}$ & $\mathrm{B}$ \\
\hline$\%$ brown foliage & 100 & 100 & 80 & 100 \\
\hline
\end{tabular}

${ }^{1} \mathrm{~B}$, brown; Y, yellow; G, green.

2 Percentage of branches with brown foliage.

3 This tree was not recorded in August in our monthly monitoring of damaged trees (Ohta et al., 2012).

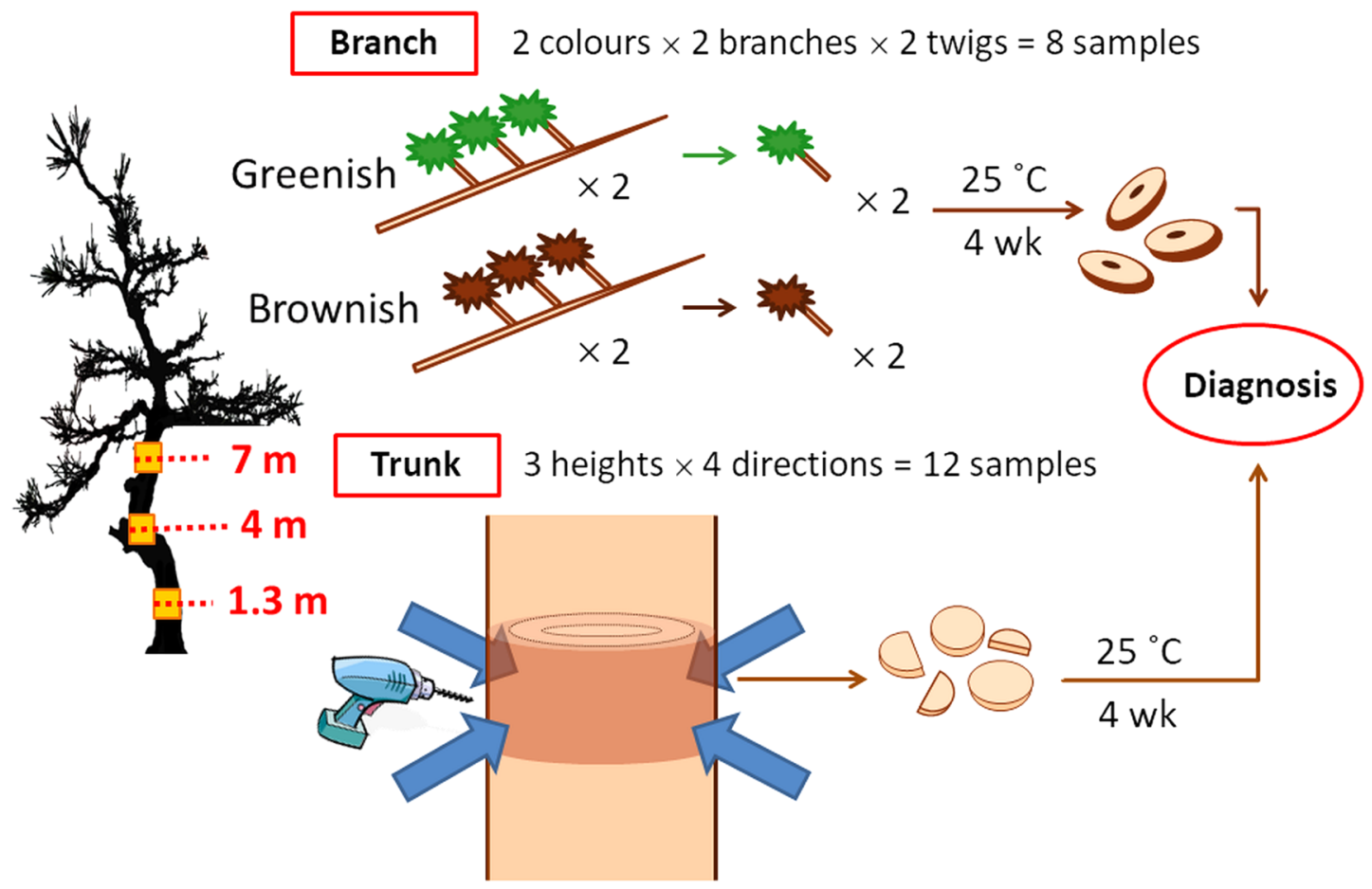

Fig. 1. The sampling scheme in each test tree. 


\section{NEMATOdE DETECTION}

To quantify B. xylophilus densities in the test tree, we adopted the Baermann funnel method, using approximately $5 \mathrm{~g}$ for each branch and trunk sample at $25^{\circ} \mathrm{C}$ for $48 \mathrm{~h}$, and B. xylophilus individuals were counted after microscopic identification of species. The amount of wood chips per sample was determined based on findings of Mamiya (1975), in which $4 \mathrm{~g}$ of wood chips was sufficient. The total amount of wood chips per tree $\left(100 \mathrm{~g} \mathrm{tree}^{-1}\right)$ was much larger than the minimum level recommended for the diagnosis for a tree $\left(>60 \mathrm{~g} \mathrm{tree}^{-1}\right.$; Schröder et al., 2009). The detection trial was conducted once for each sample $(\mathrm{n}=80$ for first diagnosis for all trees; $\mathrm{n}=20$ for the second diagnosis for Tree 2).

For molecular detection of B. xylophilus we used the Bursaphelenchus xylophilus Detection Kit. This detection kit amplifies B. xylophilus-specific DNA sequences through LAMP (Notomi et al., 2000), and then a fluorescence reaction is used for confirmation of the amplified DNA (Kikuchi et al., 2009; Aikawa et al., 2010). Compared with PCR-based nematode detection (e.g., Takeuchi et al., 2005), this LAMP-based detection kit enables detection of B. xylophilus more quickly ( $c a 90 \mathrm{~min}$. including DNA extraction) (Kikuchi et al., 2009). The amplification is highly sensitive (Kikuchi et al., 2009), and only two wood chips ( $c a 0.12 \mathrm{~g}$ ) are used for a single diagnosis trial. This high sensitivity, in turn, suggests a risk of false negatives due to the small amount of wood chips. Therefore, we carried out four trials for each sample.

As described in the instructions for the kit, nematode DNA was extracted by soaking wood chips in $800 \mu \mathrm{l}$ of extraction buffer (provided in the kit) and incubating them at $55^{\circ} \mathrm{C}$ with shaking $(65 \mathrm{rpm})$ for $30 \mathrm{~min}$. The extraction was stopped by heat shock at $100^{\circ} \mathrm{C}$ for $10 \mathrm{~min}$. Then, to perform the LAMP reaction, the extracted DNA solution $(2 \mu \mathrm{l})$ and a kit-provided reaction buffer $(18 \mu \mathrm{l})$ was incubated at $63^{\circ} \mathrm{C}$ for $90 \mathrm{~min}$. The LAMP reaction was stopped by heat shock at $80^{\circ} \mathrm{C}$ for $2 \mathrm{~min}$. After the reaction, we checked if $B$. xylophilus DNA was present ('positive'), based on fluorescence. For the test Tree 2, which showed the lowest level of B. xylophilus detection in the first sampling, additional tests were conducted in the same way using wood chips taken in the second sampling. Again, in order to avoid contamination by $B$. xylophilus DNA, we kept the laboratory clean, e.g., by wiping the laboratory bench with sodium hypochlorite before every detection trial.

To assure that DNA of B. xylophilus was precisely detected in our laboratory protocol, the detection kit was also applied to solutions with suspended microscopeidentified nematodes, and we confirmed that our diagnosis resulted in 'positive' for the solution with $B$. xylophilus but 'negative' for the solution with other species of Bursaphelenchus nematodes.

\section{DATA ANALYSES}

\section{Analysis 1}

First, we compared the two detection methods (Baermann funnel method $v s$ DNA detection kit) to test the sensitivity of nematode detection. Because our sampling was nested within each test tree, we adopted generalised linear mixed models (GLMM). The mixed model, in which random effect(s) are incorporated, is powerful in analysing data with nested/skewed structures avoiding pseudo-replication (Grafen \& Hails, 2002; Bolker et al., 2009). We examined both detection levels and nematode densities for each sample.

In Analysis 1, the response variable for detection level was the frequency of positive samples, the explanatory variable (fixed effect) was the detection method, and the random effect was tree identity. For nematode density, the response variable was the number of nematodes detected, specifying dry weight of sample wood chips as an offset term, and the same for others for the detection level. For all model calculations, R ver. 2.15.3 (R Core Team, 2013) and package 'Ime4' were used.

\section{Analysis 2}

In this analysis, we compared the detection level and nematode density between sampling positions in the trees. The detection level was based only on the DNA detection kit, because the results of Analysis 1 showed a significantly higher detection with the DNA detection kit than the Baermann funnel method. We adopted GLMMs with similar structures and parameters and examined the effects of 'branches $v s$ trunk', 'foliage colour (green foliage $v s$ brown foliage) of the branch and 'sampling height' $(1.3 \mathrm{~m} v s 4 \mathrm{~m} v s 7 \mathrm{~m})$ of the trunk (see Table 2 for complete model descriptions). For Tree 2, for which the result of the above model might have suffered from false negatives, we ran additional GLMMs, using pooled data for first and second sampling, in order to test whether the timing of tissue sampling (at early $v s$ later stage) affected the detection.

Finally, to compare the extent of variation at the individual tree level (i.e., difference in means) and that of variation among positions within the tree, variance component analysis was performed using Analysis 2. We 
Table 2. Structures, sample sizes, and estimated variance components of generalised linear mixed models in Analysis 2.

\begin{tabular}{|c|c|c|c|c|c|c|c|}
\hline \multirow[t]{2}{*}{ Response variable } & \multirow[t]{2}{*}{ Fixed effect } & \multirow[t]{2}{*}{ Random effects $^{1}$} & \multirow{2}{*}{$\begin{array}{l}\text { Parameter } \\
\text { distribution }\end{array}$} & \multirow{2}{*}{$\begin{array}{l}\text { Link } \\
\text { function }\end{array}$} & \multirow[t]{2}{*}{$\mathrm{n}$} & \multicolumn{2}{|c|}{ Variance component } \\
\hline & & & & & & $\begin{array}{c}\text { Among parts } \\
\text { within tree }\end{array}$ & Among trees \\
\hline \multicolumn{8}{|l|}{ Stem $v s$ branch } \\
\hline Detection level & Branch vs stem & Tree/part & Binomial & Logit & 80 & 1.64 & 4.20 \\
\hline Nematode density $^{2}$ & Branch vs stem & Tree/part & Poisson & $\log$ & 80 & 10.62 & 7.18 \\
\hline \multicolumn{8}{|l|}{ Foliage colour (branch) } \\
\hline Detection level & Brown $v s$ green & Tree/branch & Binomial & Logit & 32 & 1.22 & 5.59 \\
\hline Nematode density & Brown $v s$ green & Tree/branch & Poisson & $\log$ & 32 & 17.28 & 5.22 \\
\hline \multicolumn{8}{|l|}{ Sampling height (stem) } \\
\hline Detection level & $1.3 \mathrm{~m} / 4 \mathrm{~m} / 7 \mathrm{~m}^{3}$ & Tree/stem direction & Binomial & Logit & 48 & $1.49 \times 10^{-15}$ & 7.34 \\
\hline Nematode density & $1.3 \mathrm{~m} / 4 \mathrm{~m} / 7 \mathrm{~m}$ & Tree/stem direction & Poisson & $\log$ & 48 & 2.78 & 8.37 \\
\hline
\end{tabular}

1 A random effect 'part' ('branch' or 'stem direction' (N, E, S or W at each stem height)) was nested within 'tree'.

${ }^{2}$ Sample dry weight (DW) was specified as an offset term.

$31.3 \mathrm{~m}$ was set as the baseline.

calculated variance components based on the deviance values in each model, and compared the degree of different sources of variation.

\section{Results}

\section{AdVANTAge OF THE DNA DETECTION KIT}

The densities of B. xylophilus varied greatly among the test trees (Fig. 2). The density level for Tree 3 was highest $\left(\right.$ mean $=365$ nematodes $(\mathrm{g} \mathrm{DW})^{-1}$; range $\left.=0-2760\right)$, whereas that for Tree 2 was low (mean $=15.9$; range $=$ 0-295).

The overall level of B. xylophilus detection using the Baermann funnel method and the DNA detection kit was $66.3 \%$ (53/80 samples) and $81.3 \%$ (65/80 samples), respectively. The difference was statistically significant (Analysis $1 ; z=2.92, P=0.004$ ). The detection level was highest for Tree 1, followed by Tree 4 (Table 3). Tree 2 showed lowest level of detection in both methods (Table 3). For Tree 2, there was no significant difference in the detection levels between the two sampling timings $(z=1.23, P=0.22)$. For complete results on detection levels and densities of B. xylophilus, see Tables S1-S3 in the Supplementary material.

The detection kit revealed B. xylophilus infection in 14 (51.9\%) out of 27 samples for which B. xylophilus was not found using the Baermann funnel method. In the reverse comparison, only two samples were found to be positive for B. xylophilus infection via the Baermann funnel method out of the 53 samples for which the detection kit result was negative for $B$. xylophilus infection.

\section{EFFECTS OF SAMPLING POSITION ON DETECTABILITY}

Based on the DNA kit, the mean detection for trunk samples ranged from 88 to $100 \%$ for Trees 1,3 and 4 , whereas it was $27 \%$ for Tree 2 (Fig. 3A). On the other hand, branch samples showed a variety of detection levels: low (Tree 2), moderate (Tree 3) and high (Trees 1, 4) (Fig. 3A). The detection levels were on average 2.2 times higher for trunk samples than for branch samples from the same tree (Analysis $2 ; z=3.47, P<0.001$ ). There was no significant difference in the density of $B$. xylophilus between branch and trunk samples (Analysis $2 ; z=0.70$, $P=0.48)$ (Fig. 2A).

The variance component analysis revealed that variation in the detection of $B$. xylophilus originated largely from among-tree variation (Var. ${ }_{\text {among branches }}=1.6<$ $\operatorname{Var}_{\text {among trees }}=4.2$; Table 2), whereas the source of variation in B. xylophilus densities was primarily from among-branch variation (Var. ${ }_{\text {among branches }}=10.6>$ Var.among trees $_{\text {-a }}=7.2$; Table 2).

Branch samples differing in foliage colours showed no significant trend in the detection level $(z=-1.0$, $P=0.30$; Fig. 3B). This was almost the same for the densities of $B$. xylophilus $(z=-0.06, P=0.96$ ), although branches with green foliage from Tree 3 had higher B. xylophilus densities (Fig. 2B). The variance component analysis showed a similar trend for both nematode detection (Var.among twigs on the same-colour branch $=$ 


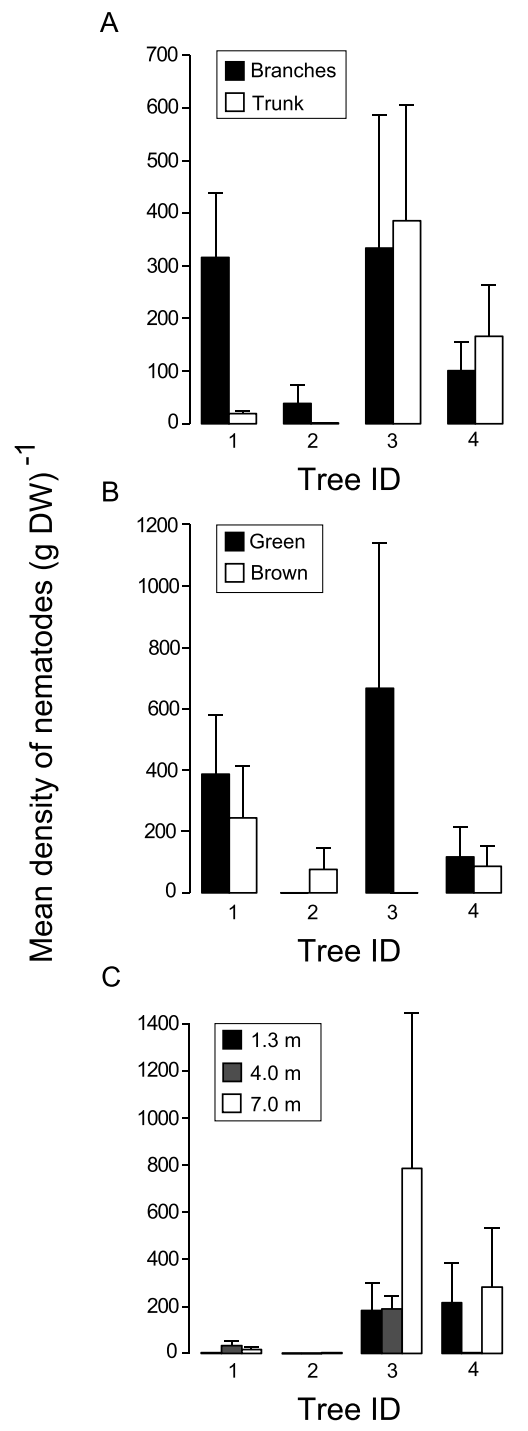

Fig. 2. Comparison of densities of Bursaphelenchus xylophilus. A: Branches vs trunk; B: Green vs brown foliage branches; C: $1 \mathrm{~m} v s 4 \mathrm{~m} v s 7 \mathrm{~m}$ (trunk). Bars represent the mean density of nematodes, and vertical lines represent standard error.

$1.2<$ Var. $\left._{\text {among trees }}=5.6\right)$ and nematode density $\left(\right.$ Var. $_{\text {among twigs on the same-colour branch }}=17.3>\operatorname{Var}_{\text {among trees }}=$ 5.2) (Table 2).

Detection levels for samples taken from differing heights were generally high (>80\% detection; Fig. 3C), except for Tree $2(6.2-37.5 \%)$. The effect of sampling height $(4 \mathrm{~m}$ and $7 \mathrm{~m}$ relative to $1.3 \mathrm{~m}$ as the baseline) was marginally significant $(z=1.80, P=0.07$ for both). As for B. xylophilus densities, samples taken from $1.3 \mathrm{~m}$ high had greater densities than samples taken from $4 \mathrm{~m}$ high $(z=-26.5, P<0.001)$ and had
A
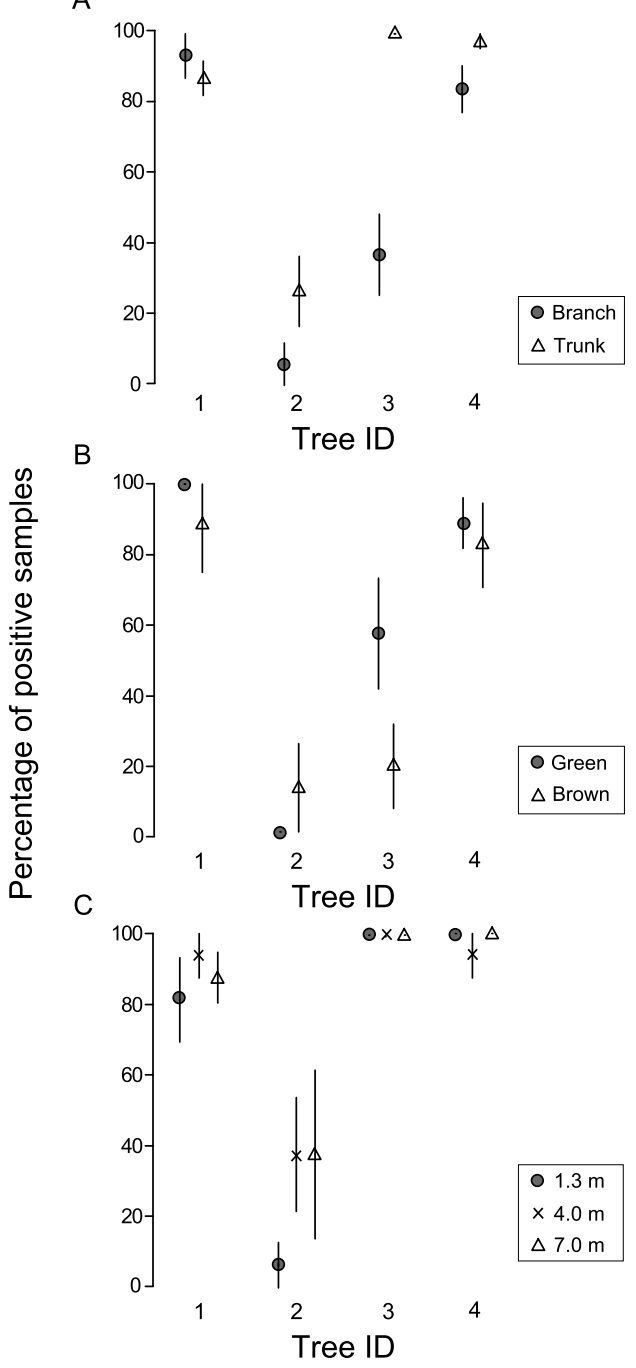

Fig. 3. Comparisons of percentages of samples showing a positive reaction for Bursaphelenchus xylophilus using the DNA detection kit. A: Branches vs trunk; B: Green vs brown; C: $1 \mathrm{~m}$ vs $4 \mathrm{~m}$ vs $7 \mathrm{~m}$. Vertical lines represent standard error.

lower density than those taken from $7 \mathrm{~m}(z=66.1$, $P<0.001$ ) (Fig. 2C). Analysis of variance components revealed that variation in both the detection and density of $B$. xylophilus originated mostly from amongtree variation (Var.among replicates within each height $=1.5 \times$ $10^{-15} \ll \operatorname{Var}_{\text {among trees }}=7.3$ for detection level;

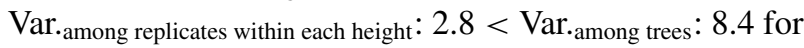
nematode density) (Table 2). 
Table 3. Detection levels of Bursaphelenchus xylophilus using the Baermann funnel technique and the DNA detection kit. Detection level is based on 20 samples for each test-tree.

\begin{tabular}{|c|c|c|c|c|}
\hline \multirow[t]{2}{*}{ Tree ID } & \multicolumn{2}{|c|}{ Baermann funnel technique } & \multicolumn{2}{|c|}{ DNA detection kit } \\
\hline & $\begin{array}{c}\text { No. of } \\
\text { 'positive' samples }\end{array}$ & $\begin{array}{l}\text { Detection } \\
\text { level }(\%)\end{array}$ & $\begin{array}{c}\text { No. of } \\
\text { 'positive' samples }\end{array}$ & $\begin{array}{l}\text { Detection } \\
\text { level }(\%)\end{array}$ \\
\hline 1 & 19 & 95.0 & 20 & 100.0 \\
\hline 2 & 3 & 15.0 & 7 & 35.0 \\
\hline 3 & 14 & 70.0 & 18 & 90.0 \\
\hline 4 & 17 & 85.0 & 20 & 100.0 \\
\hline Total & 53 & 66.3 & 65 & 81.3 \\
\hline
\end{tabular}

\section{Discussion}

In the present study, we examined the effectiveness of a DNA-based B. xylophilus detection kit in conditions in which the density of $B$. xylophilus varied greatly among host trees. Of the four trees examined, Tree 2 exhibited much lower B. xylophilus densities than other trees. For all the trees, higher detection levels were observed when the DNA-based kit was applied than when the Baermann funnel method was applied. For Tree 2, both detection and nematode density were lower than for the three other trees, and the difference between the two detection means was remarkable.

Before interpreting these results, we briefly examined whether our results suffered from false positive results, because even when the Baermann funnel method failed to detect $B$. xylophilus, the diagnosis with the detection kit showed positive reactions in $>50 \%$ of those samples and because this might occur due to the high sensitivity of the kit (Kikuchi et al., 2009). However, this possibility is very unlikely; in our previous paper, the same sampling protocol was adopted in both the field and laboratory, and we had positive results in only $1.5 \%$ of $>800$ samples with the same DNA detection kit (Hoshizaki et al., 2016). This percentage may not be obtained if we suffer from cross-contamination of DNA. Because we paid the same level of care to avoid cross-contamination in the laboratory in both the previous and present studies, false positives can be excluded in the present study.

In Analysis 1, although higher detectability was found for the detection kit, the detection level for Tree 2 was less than $40 \%$. This was consistent with the notion that false negatives may be inevitable when detecting $B$. xylophilus from trees with low nematode density (Mamiya, 1975) and suggested, in turn, the importance of efficient design of wood chip sampling in minimising false negatives.
In Analysis 2, trunk samples showed significantly higher detection levels than branch samples. This may reflect the migration habits of $B$. xylophilus after infection in a host tree. Because the nematodes usually move from infected branches to the stem (Kiyohara \& Suzuki, 1978; Zhao et al., 2009), so it may be assumed that variance in B. xylophilus density (and presence, too) may be smaller for samples taken from the stem than branch samples.

Foliage colour had no significant effect on the detection level. Intuitively, we might expect that the detection level would be higher for brown foliage branches than for green foliage branches because the population of infected $B$. xylophilus is likely to increase drastically after wilting of the host tree becomes apparent (Kiyohara \& Suzuki, 1978). However, based on our results, the reverse was true at the early stage of disease symptoms. This paradoxical phenomenon could be explained based on discordance between the positions at which B. xylophilus infection occurs and those in which wilting is triggered. In the first phase of disease symptom development, B. xylophilus is likely to infect pine trees in the branches and then move down to the stem. Settlement of B. xylophilus individuals in the stem often leads to xylem cavitation at the second phase, resulting eventually in wilting of the tree (Fukuda, 1999). Importantly, the branch experiencing wilting, i.e., having discoloured foliage, may be determined by the position at which the cavitation occurs in the stem, not by the position at which infection occurs. Therefore, in the present study the branches with discoloured foliage were independent of the branch with B. xylophilus infection. Although B. xylophilus was frequently detected from trunk samples in our results, xylem cavitation was inferred to have occurred partially in the stem of the test trees.

The effect of sampling height was marginally significant. This result has several non-decisive implications in practice. Sampling at $1.3 \mathrm{~m}$ high would be advantageous 
in terms of labour cost, but 'negative' results might be due to false negatives. Resampling at a higher position would be better when a negative result is obtained at a lower height. On the other hand, access to $4 \mathrm{~m}$ or higher on the trunk may be costly. If access to higher positions can be obtained easily, samples taken from higher positions could be better. In other words, the decision on sampling height may depend upon the forest manager(s).

Our results suggest that sampling position could be better replicated, but when we have a closer look at our data (Tables S1-S3), diagnosis for a single sample is mostly $4 / 0$ or 3/1 (denoted as 'positive'/'negative' trials), implying a marginal effect of repetition for $B$. xylophilus detectability. Within-tree variation in B. xylophilus densities in pine trees has been investigated in detail, where the densities varied both within a tree along the vertical direction and among branches (Kiyohara, 1989; Zhao et al., 2009; Hoshizaki et al., 2016). In a case study using the same DNA detection kit as in the present study, detection levels varied among positions in the wood samples used (Kanetani et al., 2011). These findings suggest the importance of replication of wood chip samples for accurate diagnosis for a given tree. However, in our GLMMs for detection level, among-tree variation was consistently larger than within-tree variation (Table 2). This indicates that tree identity is more influential for the results than within-tree positions. In other words, prioritising efforts to increase the number of trees to be examined could be more effective compared with devoting efforts to increasing the number of samples per tree. This is in accordance with the general recommendation of Schröder et al. (2009) (preferably five trees per site), although it should be noted that the number of trees to be taken for diagnosis may depend upon the disease status of the forest (Schröder et al., 2009) and the climate of the site (Zinno et al., 1987; Ohta et al. 2012).

In practice, resources for control, e.g., funding or labour costs, are usually constrained. Based on our results, and in accord with the general recommendations (Schröder et al., 2009), we recommend the following for efficient sampling for the detection of pine wilt disease; first, taking wood chips (at least $60 \mathrm{~g}$ tree $^{-1}$ ) from the trunks of as many trees as possible, and the sampling is better from higher positions (4 $\mathrm{m}$ or higher). A higher sampling position is not mandatory, keeping on the 'safe side', but false negatives cannot be discounted when nematode density is quite low. Second, diagnosis should preferably be based on the DNA detection kit with repetition (sampling with four repetitions is acceptable).

\section{Acknowledgements}

We are grateful to Prof. Akifumi Makita and Dr Inoue Mizuki for logistical support, and to volunteers of Sumiyaki de Yuhi-no-matsubara Mamoritai for helping with tree cutting in the field.

\section{References}

Abelleira, A., Picoaga, A., Mansilla, J.P. \& Aguin, O. (2011). Detection of Bursaphelenchus xylophilus, causal agent of pine wilt disease on Pinus pinaster in northwestern Spain. Plant Disease 95, 776. DOI: 10.1094/PDIS-12-10-0902

Aikawa, T., Kanzaki, N. \& Kikuchi, T. (2010). [A simple diagnostic tool of pine wood nematode 'Bursaphelenchus xylophilus detection kit'.] Forest Pests 59, 60-67.

Bolker, B.M., Brooks, M.E., Clark, C.J., Geange, S.W., Poulsen, J.R., Stevens, M.H.H. \& White, J.S.S. (2009). Generalized linear mixed models: a practical guide for ecology and evolution. Trends in Ecology and Evolution 24, 127-135. DOI: $10.1016 /$ j.tree.2008.10.008

Fukasawa, Y. (2016). Seedling regeneration on decayed pine logs after the deforestation events caused by pine wilt disease. Annals of Forest Research 59, 191-198. DOI: 10.15287/afr. 2016.572

Fukuda, K. (1999). [Physiological changes during symptom development in pine wilt disease.] Journal of Tree Health 3, 67-74.

Grafen, A. \& Hails, R. (2002). Modern statistics for the life sciences. Oxford, UK, Oxford University Press.

Hoshizaki, K., Sano, S., Sakuraba, H., Tabuchi, N., Yoshida, A., Oikawa, Y., Makita, A. \& Kobayashi, K. (2005). [A practical protection from pine-wilt disease through conversion of infected trees to charcoal: strategy for reduction of diseasevectors and a case for a coastal pine forest, northern Japan.] Tohoku Journal of Forest Science 10, 82-89. DOI: 10.18982/ tjfs.10.2_82

Hoshizaki, K., Nakabayashi, Y., Mamiya, Y. \& Matsushita, M. (2016). Localized within- and between-tree variation in nematode distribution during latent state of pine wilt disease makes the disease status cryptic. Forest Pathology 46, 200205. DOI: 10.1111/efp.12244

Kanetani, S., Kikuchi, T., Akiba, M., Nakamura, K., Ikegami, H. \& Tetsuka, K. (2011). Detection of Bursaphelenchus xylophilus from old discs of dead Pinus armandii var. amamiana trees using a new detection kit. Forest Pathology 41, 387-391. DOI: 10.1111/j.1439-0329.2010.00695.x

Kikuchi, T., Aikawa, T., Oeda, Y., Karim, N. \& Kanzaki, N. (2009). A rapid and precise diagnostic method for detecting the pinewood nematode Bursaphelenchus xylophilus by loopmediated isothermal amplification. Phytopathology 99, 13651369. DOI: 10.1094/PHYTO-99-12-1365 
Kishi, Y. (1995). The pine wood nematode and the Japanese pine sawyer. Tokyo, Japan, Thomas.

Kiyohara, T. (1989). Etiological study of pine wilt disease. Bulletin of Forestry and Forest Products Research Institute 353, 127-176.

Kiyohara, T. \& Suzuki, K. (1978). Nematode population growth and disease development in the pine wilting disease. European Journal of Forest Pathology 8, 285-292. DOI: 10.1111/ j.1439-0329.1978.tb00641.x

Kiyohara, T. \& Tokushige, Y. (1971). Inoculation experiments of a nematode, Bursaphelenchus sp. onto pine trees. Journal of the Japanese Forestry Society 53, 210-218. DOI: 10.11519/ jjfs1953.53.7_210

Leal, I., Green, M., Humble, A.E. \& Rott, M. (2007). Application of a real-time PCR method for the detection of pine wood nematode, Bursaphelenchus xylophilus, in wood samples from lodgepole pine. Nematology 9, 351-362. DOI: 10 . 1163/156854107781352098

Mamiya, Y. (1975). [Estimating population of nematodes in habiting pine wood by the Baermann funnel method.] Forest Pests 24, 114-119.

Mamiya, Y. \& Enda, N. (1972). Transmission of Bursaphelenchus lignicolus (Nematoda: Aphelenchoididae) by Monochamus alternatus (Coleoptera: Cerambycidae). Nematologica 18, 159-162. DOI: 10.1163/187529272X00395

Matsunaga, K. \& Togashi, K. (2004). A simple method for discriminating Bursaphelenchus xylophilus and B. mucronatus by species-specific polymerase chain reaction primer pairs. Nematology 6, 273-277. DOI: 10.1163/1568541041217960

Morimoto, K. \& Iwasaki, A. (1972). [Role of Monochamus alternatus (Coleoptera: Cerambycidae) as a vector of Bursaphelenchus lignicolus (Nematoda: Aphelenchoididae).] Journal of the Japanese Forestry Society 54, 177-183. DOI: 10. 11519/jjfs1953.54.6_177

Mota, M.M. \& Vieira, P. (Eds) (2008). Pine wilt disease: a worldwide threat to forest ecosystems. Dordrecht, The Netherlands, Springer.

Mota, M.M., Braasch, H., Bravo, M.A., Penas, A.C., Burgermeister, W., Metge, K. \& Sousa, E. (1999). First report of Bursaphelenchus xylophilus in Portugal and in Europe. Nematology 1, 727-734. DOI: 10.1163/156854199508757

Notomi, T., Okayama, H., Masubuchi, H., Yonekawa, T., Watanabe, K., Amino, N. \& Hase, T. (2000). Loop-mediated isothermal amplification of DNA. Nucleic Acids Research 28, e63. DOI: $10.1093 / \mathrm{nar} / 28.12 . \mathrm{e} 63$

Ohta, K., Hoshizaki, K., Nakamura, K., Nagaki, A., Ozawa, Y., Nikkeshi, A., Makita, A., Kobayashi, K. \& Nakakita, O. (2012). Seasonal variations in the incidence of pine wilt and infestation by its vector, Monochamus alternatus, near the northern limit of the disease in Japan. Journal of Forest Research 17, 360-368. DOI: 10.1007/s10310-011-0304-3

$\mathrm{R}$ Core Team (2013). R: a language and environment for statistical computing. Vienna, Austria, R Foundation for Statistical Computing.

Robertson, L., Arcos, S.C., Escuer, M., Meriono, S., Esparrago, G., Abelleira, A. \& Navas, A. (2011). Incidence of the pine wood nematode Bursaphelenchus xylophilus Steiner \& Buhrer, 1934 (Nickle, 1970) in Spain. Nematology 13, 755757. DOI: $10.1163 / 138855411$ X578888

Rodrigues, A., Casquilho, M., Oliveira, H. \& Bordado, J. (2010). A statistical analysis of the impact of nematode attack symptomatology on the mechanical behaviour of Pinus pinaster Ait. wood. European Journal of Forest Research 129, 145-153. DOI: 10.1007/s10342-009-0307-1

Schröder, T., McNamara, D.G. \& Gaar, V. (2009). Guidance on sampling to detect pine wood nematode Bursaphelenchus xylophilus in trees, wood and insects. EPPO Bulletin 39, 179188. DOI: $10.1111 / \mathrm{j} .1365-2338.2009 .02287 . x$

Southey, J.F. (Ed.) (1986). Laboratory methods for work with plant and soil nematodes, 6th edition. London, UK, HMSO.

Takeuchi, Y., Kanzaki, N. \& Futai, K. (2005). A nested PCRbased method for detecting the pine wood nematode, Bursaphelenchus xylophilus, from pine wood. Nematology 7, 775782. DOI: $10.1163 / 156854105775142928$

Zhao, L., Jiang, P., Humble, L.M. \& Sun, J. (2009). Within-tree distribution and attractant sampling of propagative pinewood nematode, Bursaphelenchus xylophilus: an early diagnosis approach. Forest Ecology and Management 258, 1932-1937. DOI: 10.1016/j.foreco.2009.07.040

Zinno, Y., Takizawa, Y. \& Sato, H. (1987). [Characteristics and control measures of pine wilt disease in cold districts and highland areas.] Tokyo, Japan, Forestry Science and Technology Institute. 
Y. Nakabayashi et al.

Table S1. Densities of nematodes (Bursaphelenchus xylophilus and other species) based on the Baermann funnel technique and diagnosis results of B. xylophilus infection based on the DNA detection kit (denoted as 'positive'/'negative' trials) for branch samples.

\begin{tabular}{|c|c|c|c|c|c|c|}
\hline Tree ID & $\begin{array}{l}\text { Foliage } \\
\text { colour }\end{array}$ & No. of branches & No. of twigs & $\begin{array}{c}\text { B. xylophilus } \\
\left(\text { nematodes }(\mathrm{g} \mathrm{DW})^{-1}\right)\end{array}$ & Level of other species 1 & DNA detection kit \\
\hline \multirow[t]{8}{*}{1} & \multirow[t]{4}{*}{ Green } & \multirow[t]{2}{*}{1} & 1 & 113 & - & $4 / 0$ \\
\hline & & & 2 & 2 & - & $4 / 0$ \\
\hline & & \multirow[t]{2}{*}{2} & 1 & 769 & - & $4 / 0$ \\
\hline & & & 2 & 668 & - & $4 / 0$ \\
\hline & \multirow[t]{4}{*}{ Brown } & \multirow[t]{2}{*}{1} & 1 & 218 & - & $4 / 0$ \\
\hline & & & 2 & 734 & - & $4 / 0$ \\
\hline & & \multirow[t]{2}{*}{2} & 1 & 10 & - & $2 / 2$ \\
\hline & & & 2 & 18 & - & $4 / 0$ \\
\hline \multirow[t]{8}{*}{2} & \multirow[t]{4}{*}{ Green } & \multirow[t]{2}{*}{1} & 1 & 0 & ++ & $0 / 4$ \\
\hline & & & 2 & 0 & + & $0 / 4$ \\
\hline & & \multirow[t]{2}{*}{2} & 1 & 0 & + & $0 / 4$ \\
\hline & & & 2 & 0 & + & $0 / 4$ \\
\hline & \multirow[t]{4}{*}{ Brown } & \multirow[t]{2}{*}{1} & 1 & 295 & + & $2 / 2$ \\
\hline & & & 2 & 9 & ++ & $0 / 4$ \\
\hline & & \multirow[t]{2}{*}{2} & 1 & 0 & + & $0 / 4$ \\
\hline & & & 2 & 0 & ++ & $0 / 4$ \\
\hline \multirow[t]{8}{*}{3} & \multirow{4}{*}{ Green } & \multirow[t]{2}{*}{1} & 1 & 2005 & + & $2 / 2$ \\
\hline & & & 2 & 665 & + & $4 / 0$ \\
\hline & & \multirow[t]{2}{*}{2} & 1 & 0 & - & $1 / 3$ \\
\hline & & & 2 & 0 & - & $2 / 2$ \\
\hline & \multirow[t]{4}{*}{ Brown } & \multirow[t]{2}{*}{1} & 1 & 0 & - & $0 / 4$ \\
\hline & & & 2 & 0 & - & $2 / 2$ \\
\hline & & \multirow[t]{2}{*}{2} & 1 & 1 & - & $0 / 4$ \\
\hline & & & 2 & 0 & - & $1 / 3$ \\
\hline \multirow[t]{8}{*}{4} & \multirow[t]{4}{*}{ Green } & \multirow[t]{2}{*}{1} & 1 & 22 & + & $4 / 0$ \\
\hline & & & 2 & 406 & + & $4 / 0$ \\
\hline & & \multirow[t]{2}{*}{2} & 1 & 12 & + & $3 / 1$ \\
\hline & & & 2 & 29 & + & $3 / 1$ \\
\hline & \multirow[t]{4}{*}{ Brown } & \multirow[t]{2}{*}{1} & 1 & 49 & - & $3 / 1$ \\
\hline & & & 2 & 284 & - & $2 / 2$ \\
\hline & & \multirow[t]{2}{*}{2} & 1 & 2 & - & $4 / 0$ \\
\hline & & & 2 & 7 & + & $4 / 0$ \\
\hline
\end{tabular}

${ }^{1}+++,>500$ nematodes;,++ 50-500 nematodes;,$+<50$ nematodes; - , Not detected. 
Table S2. Densities of nematodes (Bursaphelenchus xylophilus and other species) based on the Baermann funnel technique and diagnosis results of B. xylophilus infection based on the DNA detection kit for trunk samples.

\begin{tabular}{|c|c|c|c|c|c|}
\hline Tree ID & $\begin{array}{l}\text { Sampling } \\
\text { height }(\mathrm{m})\end{array}$ & Side & 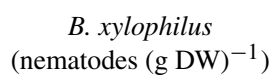 & Level of other species 1 & DNA detection kit \\
\hline \multirow[t]{12}{*}{1} & \multirow[t]{4}{*}{7.0} & $\mathrm{~N}$ & 4 & + & $3 / 1$ \\
\hline & & $\mathrm{E}$ & 43 & + & $4 / 0$ \\
\hline & & W & 4 & + & $3 / 1$ \\
\hline & & $S$ & 18 & + & $4 / 0$ \\
\hline & \multirow[t]{4}{*}{4.0} & $\mathrm{~N}$ & 89 & ++ & $4 / 0$ \\
\hline & & $\mathrm{E}$ & 18 & + & $4 / 0$ \\
\hline & & W & 17 & - & $4 / 0$ \\
\hline & & $\mathrm{S}$ & 15 & + & $3 / 1$ \\
\hline & \multirow[t]{4}{*}{1.3} & $\mathrm{~N}$ & 4 & - & $2 / 2$ \\
\hline & & $\mathrm{E}$ & 10 & + & $4 / 0$ \\
\hline & & $\mathrm{W}$ & 0 & - & $3 / 1$ \\
\hline & & $S$ & 5 & - & $4 / 0$ \\
\hline \multirow[t]{12}{*}{2} & \multirow[t]{4}{*}{7.0} & $\mathrm{~N}$ & 0 & + & $0 / 4$ \\
\hline & & E & 13 & + & $4 / 0$ \\
\hline & & W & 0 & - & $0 / 4$ \\
\hline & & $S$ & 0 & + & $2 / 2$ \\
\hline & \multirow[t]{4}{*}{4.0} & $\mathrm{~N}$ & 0 & - & $2 / 2$ \\
\hline & & $\mathrm{E}$ & 0 & + & $0 / 4$ \\
\hline & & W & 0 & + & $3 / 1$ \\
\hline & & $\mathrm{S}$ & 0 & + & $0 / 4$ \\
\hline & \multirow[t]{4}{*}{1.3} & $\mathrm{~N}$ & 0 & - & $0 / 4$ \\
\hline & & $\mathrm{E}$ & 0 & - & $0 / 4$ \\
\hline & & W & 0 & - & $0 / 4$ \\
\hline & & $\mathrm{S}$ & 0 & - & $0 / 4$ \\
\hline \multirow[t]{12}{*}{3} & \multirow[t]{4}{*}{7.0} & $\mathrm{~N}$ & 214 & + & $4 / 0$ \\
\hline & & $\mathrm{E}$ & 513 & +++ & $4 / 0$ \\
\hline & & W & 2760 & + & $4 / 0$ \\
\hline & & $\mathrm{S}$ & 166 & ++ & $4 / 0$ \\
\hline & \multirow[t]{4}{*}{4.0} & $\mathrm{~N}$ & 233 & ++ & $4 / 0$ \\
\hline & & $\mathrm{E}$ & 29 & - & $4 / 0$ \\
\hline & & W & 269 & + & $4 / 0$ \\
\hline & & $S$ & 229 & + & $4 / 0$ \\
\hline & \multirow[t]{4}{*}{1.3} & $\mathrm{~N}$ & 528 & + & $4 / 0$ \\
\hline & & $\mathrm{E}$ & 100 & ++ & $4 / 0$ \\
\hline & & W & 303 & +++ & $4 / 0$ \\
\hline & & $\mathrm{S}$ & 96 & + & $4 / 0$ \\
\hline \multirow[t]{12}{*}{4} & \multirow[t]{4}{*}{7.0} & $\mathrm{~N}$ & 1033 & + & $4 / 0$ \\
\hline & & $\mathrm{E}$ & 90 & + & $4 / 0$ \\
\hline & & W & 3 & +++ & $4 / 0$ \\
\hline & & $\mathrm{S}$ & 0 & +++ & $4 / 0$ \\
\hline & \multirow[t]{4}{*}{4.0} & $\mathrm{~N}$ & 0 & + & $4 / 0$ \\
\hline & & $\mathrm{E}$ & 3 & +++ & $4 / 0$ \\
\hline & & $\mathrm{W}$ & 7 & + & $4 / 0$ \\
\hline & & $S$ & 0 & ++ & $3 / 1$ \\
\hline & \multirow[t]{4}{*}{1.3} & $\mathrm{~N}$ & 26 & + & $4 / 0$ \\
\hline & & E & 34 & + & $4 / 0$ \\
\hline & & W & 73 & + & $4 / 0$ \\
\hline & & $S$ & 726 & + & $4 / 0$ \\
\hline
\end{tabular}

,$+++>500$ nematodes;,++ 50-500 nematodes;,$+<50$ nematodes; - , Not detected. 
Y. Nakabayashi et al.

Table S3. Nematode densities based on the Baermann funnel technique and diagnosis results of Bursaphelenchus xylophilus infection based on the DNA detection kit for Tree 2, along with differing timings of sampling.

\begin{tabular}{|c|c|c|c|c|c|c|c|c|c|}
\hline \multirow{2}{*}{$\begin{array}{l}\text { Foliage colour }{ }^{1} \text { or } \\
\text { sampling height }(\mathrm{m})\end{array}$} & \multirow[t]{2}{*}{ No. of branches } & \multirow[t]{2}{*}{ No. of twigs } & \multirow[t]{2}{*}{ Side $^{2}$} & \multicolumn{2}{|c|}{ B. xylophilus $(\mathrm{g} \mathrm{DW})^{-1}$} & \multicolumn{2}{|c|}{ Level of other species } & \multicolumn{2}{|c|}{ DNA detection kit } \\
\hline & & & & $\begin{array}{c}\text { Early } \\
\text { symptom }\end{array}$ & $\begin{array}{c}\text { After } \\
3 \text { months }\end{array}$ & $\begin{array}{c}\text { Early } \\
\text { symptom }\end{array}$ & $\begin{array}{c}\text { After } \\
3 \text { months }\end{array}$ & $\begin{array}{c}\text { Early } \\
\text { symptom }\end{array}$ & $\begin{array}{c}\text { After } \\
3 \text { months }\end{array}$ \\
\hline \multicolumn{10}{|l|}{ A. Branch } \\
\hline \multirow[t]{4}{*}{ Green } & 1 & 1 & NA & 0 & 0 & ++ & + & $0 / 4$ & $0 / 4$ \\
\hline & & 2 & NA & 0 & 0 & + & + & $0 / 4$ & $0 / 4$ \\
\hline & 2 & 1 & NA & 0 & 0 & + & + & $0 / 4$ & $0 / 4$ \\
\hline & & 2 & NA & 0 & 0 & + & + & $0 / 4$ & $0 / 4$ \\
\hline \multirow[t]{4}{*}{ Brown } & 1 & 1 & NA & 295 & 0 & + & - & $2 / 2$ & $0 / 4$ \\
\hline & & 2 & NA & 9 & 0 & ++ & ++ & $0 / 4$ & $0 / 4$ \\
\hline & 2 & 1 & NA & 0 & 0 & + & ++ & $0 / 4$ & $0 / 4$ \\
\hline & & 2 & NA & 0 & 0 & ++ & + & $0 / 4$ & $0 / 4$ \\
\hline \multicolumn{10}{|l|}{ B. Trunk } \\
\hline \multirow[t]{4}{*}{7.0} & NA & NA & $\mathrm{N}$ & 0 & 0 & + & - & $0 / 4$ & $0 / 4$ \\
\hline & NA & NA & E & 13 & 0 & + & + & $4 / 0$ & $4 / 0$ \\
\hline & NA & NA & W & 0 & 24 & - & - & $0 / 4$ & $1 / 3$ \\
\hline & NA & NA & $S$ & 0 & 35 & + & - & $2 / 2$ & $4 / 0$ \\
\hline \multirow[t]{4}{*}{4.0} & NA & NA & $\mathrm{N}$ & 0 & 5 & - & - & $2 / 2$ & $3 / 1$ \\
\hline & NA & NA & E & 0 & 0 & + & - & $0 / 4$ & $0 / 4$ \\
\hline & NA & NA & W & 0 & 33 & + & - & $3 / 1$ & $4 / 0$ \\
\hline & NA & NA & $S$ & 0 & 0 & + & - & $0 / 4$ & $0 / 4$ \\
\hline \multirow[t]{4}{*}{1.3} & NA & NA & $\mathrm{N}$ & 0 & 0 & - & - & $0 / 4$ & $4 / 0$ \\
\hline & NA & NA & E & 0 & 2 & - & - & $0 / 4$ & $1 / 3$ \\
\hline & NA & NA & W & 0 & 0 & - & + & $0 / 4$ & $0 / 4$ \\
\hline & NA & NA & $S$ & 0 & 0 & - & - & $0 / 4$ & $0 / 4$ \\
\hline
\end{tabular}

${ }^{1}$ Colour in early symptoms.

${ }^{2}$ Injection side (see Fig. 1). 